GSA Data Repository 2016120

\title{
Subslab mantle of African provenance infiltrating the Aegean mantle wedge Kaver et al.
}

\section{Modelling parameters}

The composition of the components used in the modelling of source mixing, sediment addition and melting are shown in the Table (trace element concentrations in ppm):

\begin{tabular}{|l|r|r|r|r|r|r|r|r|}
\hline Component & $\mathbf{Z r}$ & $\mathbf{N b}$ & $\mathbf{Y b}$ & $\mathbf{H f}$ & $\mathbf{T h}$ & ${ }^{\mathbf{1 4 3}} \mathbf{N d} /{ }^{144} \mathbf{N d}$ & ${ }^{206} \mathbf{P b} /{ }^{\mathbf{2 0 4}} \mathbf{P b}$ & ${ }^{207} \mathbf{P b} /{ }^{\mathbf{2 0 4}} \mathbf{P b}$ \\
\hline Aegean Depleted Mantle & 5.5 & 0.1485 & 0.365 & 0.17 & 0.0079 & 0.5131 & 18.30 & 15.475 \\
\hline Sub-slab Enriched Mantle & 8.48 & 2.91 & 0.29 & 0.25 & 0.18 & 0.512931 & 18.746 & 15.620 \\
\hline EMS sediment & 229.08 & 31.45 & 3.50 & 5.61 & 8.51 & 0.512510 & 18.9999 & 15.6784 \\
\hline
\end{tabular}

Aegean Depleted Mantle (ADM): the ADM component is based on depleted MORB mantle (DMM) from Workman and Hart (2005) with slightly increased $\mathrm{Zr}$ and $\mathrm{Hf}$ contents to obtain a better fit with the most depleted Santorini samples. There is no direct control on the isotope composition of this component and thus a composition similar to Atlantic N-MORB was adopted.

Sub-slab Enriched Mantle (SSEM): the SSEM component is derived by estimating the source composition of the Quaternary Kula alkali basalts. These alkali basalts represent melts of the sub-slab (African) lithospheric/asthenospheric mantle and do not show evidence for interaction with the Anatolian SCLM (Aldanmaz et al., 2015; Grützner et al., 2013). Rare-earth element (REE) patterns of these alkali basalts do not indicate HREE fractionation through residual garnet or amphibole in the source, but are consistent with shallow $(<60 \mathrm{~km})$ spinel stability field melting. The source composition of these basalts was calculated assuming that the Kula alkali basalts (sample 26-wav from Chakrabarti et al., 2012) represent $2 \%$ partial melts of a lherzolitic mantle (Aldanmaz et al., 2006; Sölpüker, 2007). For these calculations, the following parameters were used: incongruent batch melting (Zou and Reid, 2001) of a DMM source modal composition (Workman and Hart, 2005), the melting reaction " $0.82 \mathrm{Cpx}+0.40 \mathrm{Opx}+0.08 \mathrm{Sp}=1.0$ melt $+0.30 \mathrm{Ol}$ " for spinel Iherzolite at $1 \mathrm{GPa}$ (Kinzler and Grove, 1992) and the partition coefficient compilation from White (2013; p. 293). The resultant SSEM source agrees well with the "Western Anatolian Mantle (WAM)" source of Aldanmaz et al. (2000; 2006).

Sediment addition and melting: a hybrid, mixed ADM-SSEM source is generated by bulk mixing of the ADM and SSEM mantle components. Sediment addition was modelled by adding a $1 \%$ fluid phase derived from Eastern Mediterranean Sea sediments (sample AMS-011 from Klaver et al., 2015) to the mixed ADM-SSEM source, using fluid/solid partition coefficients $\left(4 \mathrm{GPa}, 900^{\circ} \mathrm{C}\right.$, residual rutile) from Kessel et al. (2005). For the ADM source (Santorini), Pb and Nd concentrations of DMM (Workman and Hart, 2005) where used, whereas for the enriched SSEM source (Nisyros), a Pb content of 1 ppm was assumed. Melting of the sedimentmetasomatized mixed ADM-SSEM source was modelled as variable degrees of incongruent batch melting (Zou and Reid, 2001) of a spinel-Iherzolite source with a DMM modal composition (Workman and Hart, 2005) according to the melting reaction " $0.82 \mathrm{Cpx}+0.40 \mathrm{Opx}+0.08 \mathrm{Sp}=1.0$ melt $+0.30 \mathrm{Ol}$ " for spinel-Iherzolite at 1 GPa (Kinzler and Grove, 1992) and the partition coefficient compilation from White (2013; p. 293).

\section{References}

Aldanmaz, E., Köprübaşı, N., Gürer, Ö., Kaymakçı, N., and Gourgaud, A., 2006, Geochemical constraints on the Cenozoic, OIB-type alkaline volcanic rocks of NW Turkey: implications for mantle sources and melting processes: Lithos, v. 86, no. 1, p. 50-76.

Aldanmaz, E., Pearce, J. A., Thirlwall, M., and Mitchell, J., 2000, Petrogenetic evolution of late Cenozoic, postcollision volcanism in western Anatolia, Turkey: Journal of Volcanology and Geothermal Research, $v$. 102 , no. 1, p. 67-95. 
Aldanmaz, E., Pickard, M., Meisel, T., Altunkaynak, Ş., Sayıt, K., Şen, P., Hanan, B. B., and Furman, T., 2015, Source components and magmatic processes in the genesis of Miocene to Quaternary lavas in western Turkey: constraints from HSE distribution and $\mathrm{Hf}-\mathrm{Pb}-\mathrm{O}$ s isotopes: Contributions to Mineralogy and Petrology, v. 170, no. 2, p. 1-20.

Chakrabarti, R., Basu, A. R., and Ghatak, A., 2012, Chemical geodynamics of western Anatolia: International Geology Review, v. 54, no. 2, p. 227-248.

Grützner, T., Prelević, D., and Akal, C., 2013, Geochemistry and origin of ultramafic enclaves and their basanitic host rock from Kula Volcano, Turkey: Lithos, v. 180, p. 58-73.

Kessel, R., Schmidt, M. W., Ulmer, P., and Pettke, T., 2005, Trace element signature of subduction-zone fluids, melts and supercritical liquids at 120-180 km depth: Nature, v. 437, no. 7059, p. 724-727.

Kinzler, R. J., and Grove, T. L., 1992, Primary magmas of mid-ocean ridge basalts 1. Experiments and methods: J. geophys. Res, v. 97, no. B5, p. 6885-6906.

Klaver, M., Djuly, T., de Graaf, S., Sakes, A., Wijbrans, J., Davies, G., and Vroon, P., 2015, Temporal and spatial variations in provenance of Eastern Mediterranean Sea sediments: Implications for Aegean and Aeolian arc volcanism: Geochimica et Cosmochimica Acta, v. 153, p. 149-168.

Sölpüker, U., 2007, Petrology of Kula Volcanic Province, Western Turkey [PhD Thesis: University of Cincinnati, $194 \mathrm{p}$.

White, W. M., 2013, Geochemistry, John Wiley \& Sons.

Workman, R. K., and Hart, S. R., 2005, Major and trace element composition of the depleted MORB mantle (DMM): Earth and Planetary Science Letters, v. 231, no. 1, p. 53-72.

Zou, H., and Reid, M. R., 2001, Quantitative modeling of trace element fractionation during incongruent dynamic melting: Geochimica et Cosmochimica Acta, v. 65, no. 1, p. 153-162. 


\section{Data Sources}

This supplementary material lists the sources of the data shown in Figures 2 and 3. Literature data were filtered so to only include samples for which complete trace element data are available. In order to minimise the effects of fractional crystallisation and assimilation, samples with $>57 \mathrm{wt} . \% \mathrm{SiO}_{2}$ are excluded. High-precision ICPMS and isotope dilution (ID) data are used for the $\mathrm{Zr} / \mathrm{Nb}$ vs. $\mathrm{Zr} / \mathrm{Hf}$ diagram (Figure 2b); these references are shown in bold. Only samples for which both $\mathrm{Pb}$ and $\mathrm{Nd}$ isotope compositions were determined, are included in Figure 3.

\section{Santorini}

This work; see supplementary material 1

Bailey, J. C., Jensen, E., Hansen, A., Kann, A., and Kann, K., 2009, Formation of heterogeneous magmatic series beneath North Santorini, South Aegean island arc: Lithos, v. 110, no. 1, p. 20-36.

Kirchenbaur, M., Münker, C., Schuth, S., Garbe-Schönberg, D., and Marchev, P., 2012, Tectonomagmatic constraints on the sources of Eastern Mediterranean K-rich lavas: Journal of Petrology, v. 53, no. 1, p. 27-65.

Kirchenbaur, M., and Münker, C., 2015, The behaviour of the extended HFSE group (Nb, Ta, Zr, Hf, W, Mo) during the petrogenesis of mafic K-rich lavas: The Eastern Mediterranean case: Geochimica et Cosmochimica Acta, v. 165, p. 178-199.

Zellmer, G., Turner, S., and Hawkesworth, C., 2000, Timescales of destructive plate margin magmatism: new insights from Santorini, Aegean volcanic arc: Earth and Planetary Science Letters, v. 174, no. 3, p. 265 281.

\section{$\underline{\text { Nisyros }}$}

This work, see supplementary material 1

Braschi, E., Francalanci, L., and Vougioukalakis, G. E., 2012, Inverse differentiation pathway by multiple mafic magma refilling in the last magmatic activity of Nisyros Volcano, Greece: Bulletin of volcanology, $v$. 74, no. 5, p. 1083-1100.

Spandler, C., Martin, L. H., and Pettke, T., 2012, Carbonate assimilation during magma evolution at Nisyros (Greece), South Aegean Arc: Evidence from clinopyroxenite xenoliths: Lithos, v. 146, p. 18-33.

\section{Eastern Mediterranean Sea sediments}

Kirchenbaur, M., and Münker, C., 2015, The behaviour of the extended HFSE group (Nb, Ta, Zr, Hf, W, Mo) during the petrogenesis of mafic K-rich lavas: The Eastern Mediterranean case: Geochimica et Cosmochimica Acta, v. 165, p. 178-199.

Klaver, M., Djuly, T., de Graaf, S., Sakes, A., Wijbrans, J., Davies, G., and Vroon, P., 2015, Temporal and spatial variations in provenance of Eastern Mediterranean Sea sediments: Implications for Aegean and Aeolian arc volcanism: Geochimica et Cosmochimica Acta, v. 153, p. 149-168.

\section{$\underline{\text { Kula alkali basalts }}$}


Aldanmaz, E., Pickard, M., Meisel, T., Altunkaynak, Ş., Sayıt, K., Şen, P., Hanan, B. B., and Furman, T., 2015, Source components and magmatic processes in the genesis of Miocene to Quaternary lavas in western Turkey: constraints from HSE distribution and $\mathrm{Hf}-\mathrm{Pb}-\mathrm{Os}$ isotopes: Contributions to Mineralogy and Petrology, v. 170, no. 2, p. 1-20.

Alıcı, P., Temel, A., and Gourgaud, A., 2002, Pb-Nd-Sr isotope and trace element geochemistry of Quaternary extension-related alkaline volcanism: a case study of Kula region (western Anatolia, Turkey): Journal of Volcanology and Geothermal Research, v. 115, no. 3, p. 487-510.

Chakrabarti, R., Basu, A. R., and Ghatak, A., 2012, Chemical geodynamics of western Anatolia: International Geology Review, v. 54, no. 2, p. 227-248.

\section{Denizli-Isparta volcanic (DIV) province}

Chakrabarti, R., Basu, A. R., and Ghatak, A., 2012, Chemical geodynamics of western Anatolia: International Geology Review, v. 54, no. 2, p. 227-248.

Elitok, Ö., Özgür, N., Drüppel, K., Dilek, Y., Platevoet, B., Guillou, H., Poisson, A., Scaillet, S., Satır, M., and Siebel, W., 2010, Origin and geodynamic evolution of late Cenozoic potassium-rich volcanism in the Isparta area, southwestern Turkey: International Geology Review, v. 52, no. 4-6, p. 454-504.

Platevoet, B., Elitok, Ö., Guillou, H., Bardintzeff, J.-M., Yagmurlu, F., Nomade, S., Poisson, A., Deniel, C., and Özgür, N., 2014, Petrology of Quaternary volcanic rocks and related plutonic xenoliths from Gölcük volcano, Isparta Angle, Turkey: Origin and evolution of the high-K alkaline series: Journal of Asian Earth Sciences, v. 92, p. 53-76.

Prelević, D., Akal, C., Foley, S., Romer, R., Stracke, A., and Van Den Bogaard, P., 2012, Ultrapotassic mafic rocks as geochemical proxies for post-collisional dynamics of orogenic lithospheric mantle: the case of southwestern Anatolia, Turkey: Journal of Petrology, v. 53, no. 5, p. 1019-1055.

Yılmaz, K., 2010, Origin of anorogenic 'lamproite-like'potassic lavas from the Denizli region in Western Anatolia Extensional Province, Turkey: Mineralogy and Petrology, v. 99, no. 3-4, p. 219-239.

\section{Anatolian Miocene (Ultra) Potassice (AMUP) province}

Chakrabarti, R., Basu, A. R., and Ghatak, A., 2012, Chemical geodynamics of western Anatolia: International Geology Review, v. 54, no. 2, p. 227-248.

Çoban, H., Karacık, Z., and Ece, Ö. I., 2012, Source contamination and tectonomagmatic signals of overlapping Early to Middle Miocene orogenic magmas associated with shallow continental subduction and asthenospheric mantle flows in Western Anatolia: a record from Simav (Kütahya) region: Lithos, v. 140, p. 119-141.

Ersoy, E. Y., Helvacı, C., and Palmer, M. R., 2010, Mantle source characteristics and melting models for the early-middle Miocene mafic volcanism in Western Anatolia: Implications for enrichment processes of mantle lithosphere and origin of K-rich volcanism in post-collisional settings: Journal of Volcanology and Geothermal Research, v. 198, no. 1, p. 112-128.

Ersoy, Y. E., Helvacı, C., and Palmer, M. R., 2012, Petrogenesis of the Neogene volcanic units in the NE-SWtrending basins in western Anatolia, Turkey: Contributions to Mineralogy and Petrology, v. 163, no. 3, p. 379-401.

Pe-Piper, G., and Piper, D. J., 2001, Late Cenozoic, post-collisional Aegean igneous rocks: Nd, Pb and Sr isotopic constraints on petrogenetic and tectonic models: Geological Magazine, v. 138, no. 06, p. 653-668. 